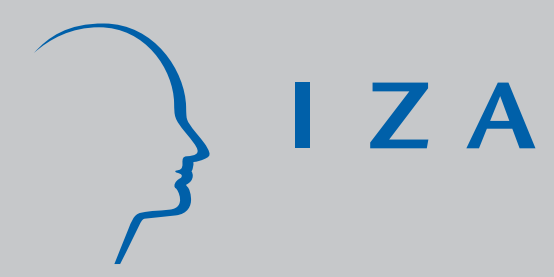

IZA DP No. 1397

Rooms of One's Own: Gender, Race and Home Ownership as Wealth Accumulation in the United States

Stanley A. Sedo

Sherrie A. Kossoudj $i$

November 2004 


\title{
Rooms of One's Own: Gender, Race and Home Ownership as Wealth Accumulation in the United States
}

\author{
Stanley A. Sedo \\ University of Michigan \\ Sherrie A. Kossoudji \\ University of Michigan \\ and IZA Bonn
}

\section{Discussion Paper No. 1397 \\ November 2004}

\author{
IZA \\ P.O. Box 7240 \\ 53072 Bonn \\ Germany \\ Phone: +49-228-3894-0 \\ Fax: +49-228-3894-180 \\ Email: iza@iza.org
}

\begin{abstract}
Any opinions expressed here are those of the author(s) and not those of the institute. Research disseminated by IZA may include views on policy, but the institute itself takes no institutional policy positions.
\end{abstract}

The Institute for the Study of Labor (IZA) in Bonn is a local and virtual international research center and a place of communication between science, politics and business. IZA is an independent nonprofit company supported by Deutsche Post World Net. The center is associated with the University of Bonn and offers a stimulating research environment through its research networks, research support, and visitors and doctoral programs. IZA engages in (i) original and internationally competitive research in all fields of labor economics, (ii) development of policy concepts, and (iii) dissemination of research results and concepts to the interested public.

IZA Discussion Papers often represent preliminary work and are circulated to encourage discussion. Citation of such a paper should account for its provisional character. A revised version may be available directly from the author. 


\section{ABSTRACT \\ Rooms of One's Own: Gender, Race and Home Ownership as Wealth Accumulation in the United States}

Do income disparities between men and women translate into longer term wealth disparities? We use the Survey of Income and Program Participation (SIPP) to investigate gender and race disparities in home ownership, value, and equity. These investigations reveal that the gap in housing outcomes is much more pronounced for the probability of home ownership than for home value or home equity. Once households have entered the housing market, differences across gender, race and family type are much smaller and sometimes turn in favor of households that are usually considered to be disadvantaged. Family type is associated with differences that are larger than those based solely on gender and are as large as those associated solely with race. The predicted probability of home ownership ranges from 0.83 for male householders in married couple households to 0.49 for male householders in non-family households. African Americans are consistently predicted to have lower home value, but less consistently predicted to have less equity than whites. We find that race gaps in homeownership, typically attributed to differences in family type (such as prevalence of female headed households in the African American population), are significantly and sizably present within gendered family types.

JEL Classification: D31, R33

Keywords: housing, wealth, gender, race

Corresponding author:

Sherrie A. Kossoudji

Department of Economics

University of Michigan

2788 School of Social Work Building

1080 S. University Ave.

Ann Arbor, MI 48109-1106

USA

Email: kossoudj@umich.edu 


\section{Introduction}

Questions about women's wealth accumulation have remained nearly unasked in the face of thousands of articles about wage and income differences between men and women. Yet wealth has always been equated with the ability to exert power in the economic, political, and social arenas. We know that substantial wealth gaps exist in the United States by income, family history, life cycle, race, and gender. Asena Caner and Edward Wolff (2003) show that African American households are twice as likely to be asset poor than white households and that for all races, female headed households, of whom 58 percent are considered asset poor, have the highest rates of asset poverty of all household types. ${ }^{1}$ Married couple householders have an average $\$ 223,194$ net wealth, male householders have an average of $\$ 111,951$ net wealth, and female householders have an average $\$ 85,319 .^{2}$

We explore the existence and extent of gendered wealth differences by examining the acquisition of a single asset-home real estate. While it is important to investigate all issues of wealth inequality and asset ownership and control, home ownership remains the single most important component of wealth for most people in the United States. William Collins and Robert Margo (2001:2) note that racial gaps in home ownership and value have an important welfare impact "because such gaps are causally related to the flow of consumption servicesshelter, comfort, public school quality, and proximity to work and recreation and so on". Housing offers the opportunity to accumulate wealth.

At the same time, it can be difficult to disentangle wealth ownership for men and women because they often live together. We ask whether the gender of the householder and the family type significantly alter the probability of home ownership and the household's accumulated

\footnotetext{
${ }^{1}$ See Caner and Wolff (2003) for the definition of asset poverty.

${ }^{2}$ See www.census.gov, wealth tables.
} 
wealth in the home. While we do not propose a theory for why this gap exists, we hope that by revealing some of the empirically relevant differences that others will be prompted to pursue this question further. We examine housing in the United States only.

\section{Homeownership Research Issues}

Home ownership is considered a hallmark of life in the United States, the principal means by which people accumulate wealth. There is a relatively small literature on gendered differences in homeownership in the United States. A survey of housing studies suggests that gender issues are typically ignored. Some articles simply omit women from the discussion (Roberto Quercia, George McCarthy, and Susan Wachter, 2003). Others skirt the question by analyzing homeownership patterns only for married couples (Joseph Gyourko and Peter Linneman, 1996). Studies of home ownership include gender through a variable that denotes a female headed household, gender, or marital status as a control variable but not as a point of discussion (Yannis Ioannides and Stuart Rosenthal, 1994; Rafael Bostic, Paul Calem, and Susan Wachter, 2004).

While there are studies of gender related differences in homeownership from other countries, their numbers are also limited. Warren, Rowlingson and Whyley offer a comparison of differentials among various asset types in Great Britain. They find that housing wealth is similar for single males and females. However, for unmarried parents there is a large discrepancy in housing wealth. Smith (1990) investigates the role of income on housing among single Australian adults. She finds that among renters, males have lower outlays for housing than females. However, for homeowners, the reverse is true, indicating that males are more able to obtain access to the potential increase in wealth available from this asset.

The constraints to ownership are numerous and women often find themselves on the wrong side of the barriers to purchasing a home. Two barriers stand out: Women earn less than 
men, on average, and higher incomes are associated with an increased ability to save and with higher credit scores. Women are more likely than men to live in single earner households with children—raising the "obligation ratio", or the competing need for the use of resources. Bostic, Calem, and Wachter (2004) review the literature and identify income, wealth, and credit constraints as the reasons that people are unable to purchase a home. In an investigation of the impact of affordable lending efforts, Robert Quercia, Roberto McCarthy and Susan Wachter (2003) identify the populations associated with such constraints as African American, households with low to moderate income, central city residents, and young households.

Women as independent householders and decision makers are not typically addressed as such. Gender may not have been a focus of housing studies because men and women often live together and because housing studies often use the household as the unit of analysis - ignoring intrahousehold issues. When women do emerge in this literature, they are identified through family type, typically as female heads of households. Collins and Margo (2001), extending previous work on racial gaps in homeownership and value over the $20^{\text {th }}$ century, find household organization critical when they include female headed households (only male heads of households were included in their previous work). Gyourko and Linneman (1996) ask about changes in home ownership patterns over time and conclude that marital status and family type are declining while the returns to skills and race are increasing in importance.

People in minority populations and women living in non-traditional family types may find that the most notable barrier to home ownership is the decision by mortgage lenders to deny loan applications. In a now famous study of mortgage lending, Alicia Munnell, Geoffrey Totell, Lynn Browne, and James McEaneany (1996:39) found that "even after accounting for the applicant's obligation ratios, wealth, credit history, and loan-to-value ratio, property, 
neighborhood and lender characteristics, as well as the stability of income, and whether he or she received private mortgage insurance, the race of the applicant still plays an important role in the lender's decision to approve or deny the loan”. Martha McDonald (2002) extends their analysis and finds that the impact of familial status discrimination is different by race for male-female couple households. McDonald has very small sample sizes for non-couple households but finds that familial status discrimination is less onerous for men than women. Family type is an important determinant of home ownership from both the demand and supply sides. Yet almost nothing is known about these differences across family type.

Women have traditionally acquired property through marriage or inheritance. Before women were likely to be active participants in the labor market, women gained a home by marrying a man who could afford one. Later, as women became active labor market participants, couples in two income households were more likely to own a home than couples in a single income household (perhaps because of income differences). Almost nothing is known about people who do not live in married couple households.

\section{The Empirical Strategy}

The analytical plan is to investigate gender and race disparities in housing by estimating differences in housing outcomes by gender, race, and family type. We want to ascertain overall gender disparities, disparities that arise because of differences in family type, and differences that arise within family type. Race must be considered because there exists significant racial disparities in housing even within gender and family types. There are three housing outcomes investigated in this article. The first is home purchase. When a person purchases a home, monthly payments contribute to wealth as well as providing shelter. For home purchasers, potential wealth from the housing asset is contingent on the value of the home. We use home 
value as a measure of long run potential wealth. As monthly payments to a home accumulate, savings accrue in the form of home equity. We use equity as a measure of current wealth.

\section{The Data Source}

We use the 1996 Survey of Income and Program Participation (SIPP) as a data source. SIPP is a large panel survey conducted by the Census Bureau, and is nationally representative. The 1996 panel, the latest SIPP panel available, has a total of four years of information that range in time from 1996 to $2000 .^{3}$ Each household has a reference person, who we will refer to as the householder. ${ }^{4}$ These householders constitute the observations in the sample. The sample was restricted to householders of age 25 or older (with no upper age restriction), those not living in mobile homes (this is because of the ambiguity of the common practice of owning the mobile home but renting the land it sits on, and because mortgage information is not available for those in mobile homes), those not living in institutional group homes, and to white and African American respondents in the sample. Those who self identified as Native American or Asian were dropped from the analysis because race plays a critical role in housing outcomes and there were too few Asian and Native American respondents for a clear analysis of the type handled in this paper. ${ }^{5}$ There were 22,904 householders in the final sample (unweighted sample size).

This analysis is mute to the issue of home ownership within the household because housing questions are asked of the reference person and then the same answers are put in the records of all individuals in the household. Data for spouses or other family members, then, is not independent information. SIPP survey procedures call for the person in whose name the household is owned or rented to be called the reference person of the household. If a married couple jointly owns the house (or jointly signs a lease), either may become the reference person

\footnotetext{
${ }^{3}$ The exact dates depend on the timing of the initial round of interviews, which ran through 1996.

${ }^{4}$ Householder does not mean homeowner. Householders may own their own homes or rent them.

${ }^{5}$ Race, in this article, refers to the self-identified race of the reference person of the household.
} 
of the household. The choice of reference person may, in fact, be telling about power relations within the household but we are unable to substantiate this. Men may be more likely to be considered to be the reference person in the household; if so, this method of data collection fails to consider how spouses or partners, the majority of whom may be women, might respond differently to questions about housing assets. Any biases that result from this data collection strategy are present in our analyses. Hopefully, our will spur future work that assesses wealth by looking within family type to individual adults in the household.

We use the latest housing information from SIPP. This housing information is pertinent to 1999 or 2000 . The cross-section weights of that time period are used for all predictions and descriptive statistics. When we use the phrase "homeownership rates" or "homeowners", we really refer, as most people do, to people who own or are buying their homes.

The SIPP data set was chosen for this analysis because it is the latest, large scale, nationally representative data set available that has detailed information about housing and assets. This affords us an opportunity to consider a number of basic questions that have not previously been asked. The use of a large scale data set is useful to address many of these questions and to provide a base for those who wish to go on to investigate more detailed questions that may be generated from studies such as this one.

\section{The Estimated Equations}

We explore these outcomes by estimating two sets of bivariate empirical equations with maximum likelihood procedures. The first set of bivariate equations estimates home value jointly with the probability of homeownership as a selection equation. The second set of equations estimates equity held in a home, again with the probability of homeownership as a 
selection equation. Both home value and equity are measured in 1999/2000 dollars. Home equity is the total property value minus any mortgage debt.

The underlying equation in each of the systems is the probit estimation of the probability of home ownership. This equation, jointly estimated with the equations for home value and home equity, both informs us about the determinants of home ownership and computes the sample selection correction variable used in the other equations. This procedure is a now common way to correct for selection bias, which exists in the other equations. Value and equity are only computed for homeowners; if there is a significant selection — and there is —into home ownership, this selection would bias the results if left uncorrected. ${ }^{6}$

\section{Family Types in the Analysis}

The analysis specifically compares housing outcomes for householders in different family types, without exploring why people live in different family types. Eeach set of equations is estimated separately for householders in each of six gendered family types. The traditional family type, of course, is the married couple household. Census statistics have shown that this family type has declined in prevalence over the years. In the SIPP sample, only 55 percent of the householders live in married couple households. We articulate three overall family types that are then separated into those with a female or male householder: householders in "married couple" families (55.0 percent of the sample), in "non-married couple" families (14.6 percent of the sample), and in "non-married couple" non-families (30.4 percent of the sample). In SIPP, a family is defined as two or more people related by birth, marriage, or adoption who reside together. A non-family is a household maintained by a person who lives alone, or with non-

\footnotetext{
${ }^{6}$ The systems are estimated using the Heckman procedure in Stata. In each set of estimates, the hypothesis that rho $=0$ (or that there was no systematic selection) was rejected at any significance level.
} 
relatives only. ${ }^{7}$ These family types are important to the analysis because, as was observed in the literature, there may be lender bias by family type, differences in behavior by family type, or systematic credit score differences by family type (not based on bias but, because of systematic differences in income). We cannot specifically say whether and how there are differences in bias, systematic credit scores, or behavior by gender within or across family type. We can, however, document differences in outcomes that result from all of them, and point toward potential explanatory factors. Past work suggests that if such differences exist, they may also exist by the gender or race of the householder even within family type.

Table 1 documents the distribution of gendered family types used in this article for the entire sample, for African Americans and for whites. White householders are more likely than African American householders to live in married couple households. About 41 percent of white householders and 23 percent of African American householders are male householders in married couples. About 17 percent of white householders and 12 percent of African American householders are female householders in married couples. ${ }^{8}$ Conversely, 28 percent of African American householders but only 9 percent of white householders are female householders in “non-married couple” families. Householders in non-married couple households may be widowed, divorced or separated, or never married.

\footnotetext{
${ }^{7}$ It is not possible to distinguish gay couples nor heterosexual couples who are partnered without marriage for this analysis. A gay man living with his partner would be considered a male householder of a non-family household. Such work may be possible in the future.

${ }^{8}$ It is important to note that every married couple householder also has the other person in the couple living in the household - even though they are not officially part of this sample. When we calculate a probability of home ownership for male householders in married couple families, we also implicitly calculate the same rate for their female spouses (and vice versa for female householders in married couple families). We caution readers not to interpret differences in outcomes for male and female householders in married couple families as differences for men and women.
} 


\section{Variables in the Analysis}

We follow the real estate housing research variable strategy but estimate the equations separately for householders in different family types. Undoubtedly, the critical variable of interest is earned income. Mortgage lenders rely heavily on permanent income in their credit scores and householders rely on it when making housing decisions. Permanent income is considered an important determinant of the ability to purchase a home. We calculate permanent earned household income, but given the short panel it is more adequately called "smoothed income". It is the average household earned income over all twelve waves of the panel (or waves in which that household was observed. It is entered separately for those who are listed as ever having retired from a job (but are now working in another). It has also been argued that more educated individuals behave differently than their less educated counterparts. Dummy variables are included for householders with a high school diploma or less education, and with some college. The omitted category is householders with at least a four year college degree. We also include a dummy variable for immigrants. Whether the householder self-identifies as African American is included as a dummy variable and solely captures the myriad ways that race influences homeownership outcomes. Similarly, whether the householder self-identifies as Latino is included as a dummy variable and solely captures the variety of ways that this ethnicity influences home ownership outcomes. ${ }^{9}$

Housing prices and the desire to own homes both vary by location. Rural residents do not live in any of the approximately 100 identified MSA cities or city groups in the United States. The large city dummy identifies residents live in the largest cities from everyone else,

\footnotetext{
${ }^{9}$ The African American dummy comes from the race variable in SIPP while the Latino dummy comes from the ethnicity variable. A householder can identify with both characteristics and, if so, is coded one for each dummy variable.
} 
where housing prices are the highest and where renting is a more common housing strategy. ${ }^{10}$ Householders who live in cities, but not the largest cities are coded zero for rural and zero for large city. We use the standard census measure of income required to be above the poverty line for each household in each residential location to account for housing and rental prices that vary by location. Following others, we note the age-life-cycle association with the choice of homeownership. Age (and age squared) are included in the home ownership probability equation. We also include the number of children in the household since the decision to purchase a home often depends on this aspect of family structure and because mortgage lenders calculate an obligation ratio based partly on this information.

Age and children are not included in the equations that determine value or equity. Instead, the length of time the home has been owned and whether the loan was purchased through an FHA mortgage are included in those equations. ${ }^{11}$ A dummy variable for people who have ever retired from a job is included in the homeownership equation (since retirement may alter preferences for ownership over renting), but not in the value or equity equations (retirement itself shouldn't influence those values). The equity equation includes an instrumental variable for value (so that equity comparisons do not also include value differences). ${ }^{12}$

By definition, all people in married couple households are married. However, for householders in "non-married couple" families and non-families, we include dummy variables to indicate whether the family head is divorced or separated, or widowed. The omitted category is

\footnotetext{
${ }^{10}$ The cities are Atlanta, Boston, Chicago, Dallas, Detroit, Miami, Los Angeles, Houston, New York, Phoenix, Philadelphia, San Francisco, Seattle, and Washington, DC.

${ }^{11}$ FHA mortgages come from the Federal Housing Association and represent a long standing program within the United States government to promote home ownership and to expand ownership for first time homebuyers and traditionally underserved populations. FHA mortgages are important to this analysis because householders with poor credit histories may still qualify for an FHA mortgage and FHA mortgages require a lower down payment than commercial mortgages (thus influencing both value and equity).

12 The instrumental variable for value is the predicted value from the value equations, divided by the poverty line income for the household.
} 
never married. Table 2 provides descriptive statistics for all of the variables used in the analysis for householders in each family type.

This table reveals that male and female householders in married couples are remarkably similar and there may be no functional reason for the choice of gender of the householder. Householders in other family types possess more barriers to saving and home ownership. They are less educated and they have lower earned income (and the female householders in each family type have less income than the male householders in that family type). Householders in "non-married couple" families are more likely to be immigrants, Latinos/as, and African American. Householders in non-family households are also less educated, have lower earned income (with female householders having significantly lower earned income than their male counterparts), are more likely to be retired, and be African American. Both women and men in families are more likely to be divorced than women and men in non-families.

\section{Homeownership In the United States}

\section{Is there a Gender Gap?}

Is there a housing ownership gap by gender similar to the income gap? Overall, 70 percent of the householders are homeowners, but male householders have a homeownership rate of 74 percent, while only 65 percent of female householders are homeowners - a statistically significant difference. There is also a discrepancy in home value and equity for homeowners in the sample. Among homeowners, male householders own houses with 8.9 percent more value than female householders. However, when comparing equity, the gap narrows to 3.2 percent. A gender gap appears to exist, but its complexities are evident when we examine homeownership by family type (see Table 2). Male and female householders in married couples are nearly equally likely to own their own homes ( 83 percent of male householders and 82 percent of 
female householders). Just over 61 percent of male householders only 48 percent of female householders in "non-married couple" families but in own their own homes. Among non-family householders, 49 percent of the men, but over 60 percent of the women are homeowners. Similarly, householders in "non-married couple" households have lower home value and lower equity than married couple householders and female householders' value and equity is typically, but not always, lower than for male householders'. Part of the ownership gap exists because men and women live in different family types.

\section{Preliminary Estimation and Discussion of Gender}

In order to gain a better understanding of the size of the gender gap separately from the role of income and other characteristics associated with home ownership, we estimated the regression equations for all households regardless of family type, controlling for gender, income, age and other characteristics. These results provide further evidence of the complexities of the discussion of gender and housing. ${ }^{13}$ Even though female householders are less likely to own their own homes, when other characteristics of the household are accounted for in the regressions, female householders are actually 3.9 percentage points more likely to own homes than male householders. There is no statistically significant difference of home value nor of home equity by gender of the householder.

While our primary focus is on gender disparities in homeownership, race is inextricably intertwined with all housing outcomes for both genders. The simple model reveals that African American householders are 12.5 percentage points less likely to be homeowners than white householders. Furthermore, the value and equity in African American homes are estimated to be $\$ 39,461$ and $\$ 27,727$ lower than that of white householders, respectively. While similar

\footnotetext{
${ }^{13}$ In order to avoid too many tables, these preliminary results are not included in a separate table, but are available from the authors until January of 2007.
} 
results exist for Latinos/as, the effects are much smaller. Latino householders are 5.7 percentage points less likely to own a home, and have values and equities that are $\$ 12,367$ and $\$ 9,448$ lower than non-Latino/a householders.

We next estimated the model for ownership on all households, including all of the control variables and using race and family type as dummy variables. ${ }^{14}$ Householders in every family type except female householders in married couples are significantly less likely to be homeowners than male householders in married couples and the size of the difference is substantial and statistically significant. Further, even after controlling for family type, white householders are significantly more likely than African American householders to own their own homes. The gender of the householder makes little difference to home ownership probabilities within overall family types (there is no significant difference between male and female householders within family type). But the family type itself is associated with significantly altered probabilities of home ownership. Compared to male and female householders in married couples, householders in all other family types are less likely to be homeowners. At the same time, there is little difference in home value or equity for householders in other family type in these preliminary equations, and where there is, women own houses with more value than men.

\section{Gender, Race and Family Type and Homeownership}

Three critically important findings developed from this preliminary work. The first is that even though female householders are less likely to be homeowners than male householders, once other characteristics (such as the variation in permanent income) have been considered, female householders are more likely to be homeowners. The second is that the delineation of the householders' relationships into family type is a key to understanding the probability of home

\footnotetext{
${ }^{14}$ The Wald $\chi^{2}$ is significant at any level in every equation. While not every single variable's coefficient is significantly different from zero, almost all of them are in every equation.
} 
ownership but not necessarily home value nor home equity. The third is that family type is not principally responsible for disparities in home ownership between African American and white householders. Even within family types there is a significant gap between white and African American householders' probabilities.

\section{How does gender matter? How does race matter? How does family type matter?}

Given the findings above, an important task of this paper is to understand the disparities in homeownership outcomes for householders of different genders and races in different family types. Are gender differences in home ownership the result of systematically lower earnings - a critical determinant of an acceptable credit score for mortgage lenders—for women? Or does the fact that men and women (and African Americans and whites) live in different family types, which may be treated differently in the housing and mortgage markets, may behave differently, and may have different financial obligations, reduce the opportunities to purchase a home? The regressions on which the following discussion is based are reported in Table 3. For this discussion, we look at housing outcomes within each family type. First we discuss each outcome separately and report on the results of the regressions. Then, within each outcome discussion, we present a graph of the outcome predicted for every single householder in the sample if he or she were subject to the "returns" of each of the explanatory variables in different family type equations. Finally, we do a full decomposition analysis for home ownership, the principal outcome that reveals gender differences.

All together the home ownership, value, and equity equations reveal a consistent story. Owning ones' home requires getting a foot in the door and it is less common for any householder, male or female, that is not in a married couple household, to pass that hurdle. There is significant evidence that the common perception of lower housing wealth for women and for 
African Americans is generally correct. We add to this the evidence of lower wealth for nonmarried men. However, if non-married men and women and African Americans of any marital status are able to purchase a home, they appear to act in ways to mitigate differences by overinvesting in housing relative to their economic status. We cannot, in this article, speak directly to prejudice and discrimination in lending markets because we have no information about attempts to purchase homes that were failed efforts because of an inability to acquire a mortgage. We also cannot speak directly to any attitude or preference differences about a home purchase as it varies by family type. However, we try to gauge the impact of these two phenomena in this section.

Home Ownership. The ways in which householders' characteristics influence the probability of owning a home are generally consistent across different family types. For householders in each family type, the relationship between permanent earned income for the household and home ownership is strong and has a concave shape. Increases in income are more important to homeownership at lower income levels than at high income levels. Householders who live in rural areas and householders who live in very large cities are less likely to own their homes than householders in other cities if there is a significant difference. Age, like income exhibits a concave shape for householders in all family types. For householders who do not live in married couple families, widows are generally more likely to own their own homes than either never married or divorced or separated householders (there is no difference between the latter two groups). African Americans, and Latinos/as where significant, are less likely to own their own homes. Overall, for whatever underlying reason, the pattern of the impact of householders' characteristics on the probability of owning a home is similar for all householders, regardless of gender and family type. 
There are differences by the gender of the householder within the basic pattern. The marginal increase in the probability of owning a home with a college education (over a high school diploma) exists principally for women; there is no significant increase with a college degree for male householders in "non-married couple" families and non-families. Importantly, some college (but not a four year degree) is also significant only for female householders in "non-married couple" families and non-families. The marginal impact of education (and other characteristics) must be interpreted carefully. For example, a college education is associated with a 15.4 percentage point increase in home ownership among female householders in "non-married couple" families (a college education significantly and substantially increases a college educated householder's home ownership probability relative to a householder in the same family type who had only a high school diploma) but a college degree does not change ownership probabilities for male householders in "non-married couple" families (male householders in "non-married couple" families with a college degree are no more likely to own homes than male householders with only a high school diploma). The impact of age increases and decreases more rapidly with age for male relative to female householders in married couples but the reverse is true for householders in non-married couple households (see below). The marginal impact of income has a slightly more concave shape for female householders than for male householders, and the marginal addition to the probability of home ownership is much stronger, dollar for dollar, for women than for men over all relevant income ranges. Women appear to convert higher earnings and more education into housing more than men.

No matter what the family type nor the gender of the householders, African American householders are less likely to own their own home and the results raise some perplexing questions. African American male householders in married couples are 7.3 percentage points 
less likely than white male householders in married couples to own their own homes. For female householders in married couples, the marginal difference is 7.6 percentage points. African American female householders in families (-6.0 percentage points) and in non-families (-7.5 percentage points) follow this pattern consistently. For all African American women and for African American men in married couple households, this gap of approximately seven percentage points represents a consistent pattern. But African American male householders in non-married couple families are a startling 21.6 percentage points and African American male householders in non-families are 17.0 percentage points less likely to own their own homes than their white counterparts. Why are their probabilities so much lower?

There does not appear to be a strong home ownership gap for Latinos/as compared to other householders but the gap that exists should act as a warning bell. Latino/a householders are as likely to own their own homes as other householders in all family types except female householders of married couple families ( 7.5 percentage points less likely than others) and female householders in non-families (10.4 percentage points less likely than others).

While the results discussed above provide an important context, it can be difficult to compare marginal coefficients across structures. In order to facilitate a comparison, we graphed the predicted rates of ownership every householder in the sample using the coefficients of each family type by age. These predictions apply to a random person in the population. Suppose any householder were able to translate income, education, etc. into housing assets subject to same regime as male householders in married couples. What would be the predicted probability of home ownership? We do this six times — once for each of the gendered family types. Any differences in probabilities across the lines represents differences in the way that characteristics get translated into housing through the different coefficients (not through differences in 
characteristics). Figure 1 does not explicitly identify the race of individuals, but is based on regressions that account for race. The legend identifies the regression from which home ownership predictions are made. With these predictions, we measure the strength of differences in the ways that income, race, education, age, etc. were translated into housing assets for people in each of the six gendered family types and then to try to understand how much the "returns" to characteristics, which includes the effects of both differences in opportunities and preferences, are responsible for the housing ownership gap by family type.

For all family type predictions, the probability of owning one's home increases by age until the age of 50 to 55. After age 50, the rate of increase is much smaller for married couple households and male householders in families, while the probabilities actually decline for the other three family types. There is a significant and deep home ownership gap between married couple householders and all other householders. The top two lines, which are virtually interchangeable, represent home ownership in married couple households. Home ownership for married couples, whether the householder is a woman or a man, is typically 10 percentages points higher than the next highest prediction for every age. We are unable to say what distinguishes a male from a female householder in a married couple household. If the determination of the reference person in the household is capricious, then we would expect those two lines to be interchangeable. The predictions for "non-married couple" families are higher than the predictions for non-families but the difference is much smaller than for married couple householders and each of those two family types. It is striking that the age relationship turns negative for female householders in "non-married couple" families and of non-families. We are unable to determine why the predictions in female householders in "non-married couple" households exhibit a pattern that rapidly narrows the gap in ownership at young ages (both with 
married couple householders and with men in their own family type), but then exhibits a decline in home ownership at older ages that reopens the gap for "non-married couple" families and eliminates the positive advantage eventually predicted for women in non-families.

\section{Home Value.}

A home's value represents potential wealth for the household. Just as with the probability of home ownership, the broad pattern of determinants of home value is similar across the six gendered family types. For householders in any family type, more education is associated with a higher home value. Contrary to the finding on home ownership, even some college education translates to increased home value for all householders. Home value also increases with permanent household earnings, and this relationship is typically large and convex where significant. Income adds to the marginal value of a home more at higher income levels than at lower income levels. Householders in large cities have higher valued homes, no matter what their gender or family type. Surprisingly, there is no value difference by marital status for householders in "non-married couple" households.

Latino/a householders do not consistently have lower home values than non-Latinos/as. Latino male householders in married couple families have \$12,639 lower home values than nonLatino men, while Latina householders in "non-married couple" families have \$17,404 lower home values than other women, and Latina householders in non-families have $\$ 24,209$ lower home values. This is potentially important because urban residence has been accounted for in these regressions. African American householders have lower home values than white householders in every family type (except male householders in non-families) but the variation in values is notable. The gap in home values ranges from zero for African American male householders in non-families (relative to white male householders in non-families) to $\mathbf{- \$ 5 1 , 4 8 6}$ 
for African American female householders in non-families (relative to white female householders in non-families).

There are gender differences in the size of the coefficients. The marginal home value associated with education is positive for male and female headed households but men convert their education to value (relative to men in the same family type) at a higher rate than do college educated women (relative to women in the same family type). Male college graduates in married couple households have houses valued $\$ 54,043$ more than men in married couple households with a high school diploma or less education, while for female householders the value added is $\$ 47,037$. For male and female householders in "non-married couple" families the additional home value of a college education is $\$ 56,130$ and $\$ 36,788$. For male and female householders in non-families the additional home value of a college education is $\$ 49,374$ and $\$ 33,923$.

Again, to facilitate comparisons across family types, we graph predictions of home values across age using the coefficients from each family type regression, but the characteristics from all householders in the sample. These predictions are illustrated in Figure 2. The value predictions show that gender plays a larger role in home value — but principally at the bottom. Using the coefficients from the male householders in non-families and female householders in married couple families consistently lead to the highest (and very similar) home values until the age of 60 when their values fall relative to others'. Those predictions are followed (with a gap at lower ages) by those for male householders in married couple and in non-couple families. Lagging considerably far behind are predictions for female householders in non-couple families and female householders in non-families. Importantly, if we performed the same exercise for the home value predictions for different household earnings levels rather than age, then, except at the highest income levels, there is almost no value gap except for that between female householders 
without a marriage partner and all other households (graph not shown). Thus, lower values for householders without a marriage partner probably result from lower incomes generally. In addition, the fact that men and women have different earnings opportunities, and generally lower incomes may translate into lower home values for women who are not married to a man than for men who are also not married. But a gap in predicted value remains when using the coefficients for unmarried women even at the same earnings levels. The gap that remains may result from the impact of preferences of women who do not live with a married partner or because mortgage lenders rate unmarried women less favorably than unmarried men.

Home values fall significantly for older households. Although it is difficult to assert for sure, we believe this reflects both a tendency for older people to live in smaller houses (a generational effect) and that the lower valuation of housing among older people (this is selfreported home value) stems from the fact that they have lived in their house for a long time and do not have a good sense of home value. In general it is important to remember that all home values and equities are self reported and if there is systematic bias by age or by the gender of the householder our results will reflect this.

Home Equity. While home values may reflect future wealth, they may also be an indication of constraints such as credit access. On the other hand, equity is a measure of the current contribution of housing to the wealth of a household. The six sets of equity equations are much less consistent across family type than the value or home ownership equations. Education is significantly positively associated with higher equity for married male and female householders, but only for female heads of families for non-married householders. Household earnings are also less consistently associated with equity, and the result of the negative coefficient on earnings and the positive coefficient on earning squared is a nearly flat earnings 
contribution to earnings except at higher earnings levels where earnings contribute positively to home equity. This unusual effect may reflect in part, the ability of householders with higher earnings to gain better access to credit markets that allow them to reduce their equity. It may also arise because people with higher earnings have more confidence about their financial security and "pull" more equity out of a home to use for other purposes. Higher household earnings is not associated with higher equity overall.

Living in a large city is positively associated with equity for male and female married couple householders and for female householders in "non-married couple" families and nonfamilies, but not for either group of non-married male householders. Consistently, householders add to equity with each year of owning a home. Following the pattern of home value, there is no difference, among non-married couple householders in any group, between those who were widowed, those divorced or separated, and those who have never been married.

Issues of race and ethnicity are murkier when equity is the considered outcome. Latino/a householders never have significantly lower equity than non-Latino/a householders in any family type. Further, African American male householders in "non-married couple" families and in non-families have the same equity as white householders. African American householders in other family types do have less equity than white householders, but the equity gap is much smaller than the value gap. The home value gap is $\$ 36,573$ for African American male householders in married couple families, but the equity gap is only $\$ 21,309$. The home value gap is $\$ 46,035$ for African American female householders in married couple families but the equity gap is only $\$ 38,399$. For African American female householders in "non-married couple" families the value gap is $\$ 40,142$ and the equity gap is $\$ 36,051$ and for African American female householders in non-families the value gap is $\$ 51,486$ while the equity gap is only $\$ 30,182$. 
These results on equity may suggest a direction for future research. Conditional on having purchased a home, and its value, the amount of in the house can be manipulated by the household. While mortgage payments must be made, the size of the mortgage, whether the house is refinanced as its value goes up, and whether advance payments are made on the mortgage to reduce the principal of the loan are all at the discretion of the householder. More income is associated with more value, but not necessarily with more equity. While more education is associated with more value, it is not often so for equity. Female householders do not have less equity than male householders, everything else equal. Neither do Latino/a householders relative to non-Latinos/as. African American householders do not consistently have less equity than white householders, everything else equal. One possible interpretation is that people who are more financially vulnerable are risk averse when it comes to equity. they are more likely to invest deeply in their homes.

It is true that the "returns" to characteristics in non-family households are such that equity predictions are low at every age relative to other family types. In Figure 3 we compare equity predictions using the coefficients from each family type. Among householders under the age of 50 , there is little predicted equity difference using the coefficients from male and female householders from either the married couple or "non-married couple" family equations. There is a large gap between them and non-family predictions with the female householders in nonfamilies line the lowest of all. At older ages, using the coefficients from female householders in married couples and in "non-married couple" families lead to declining equity. By the oldest ages, their equity has fallen almost to the level as that predicted in non-family households.

Decomposing Home Ownership. For each family type regression, race is entered as a dummy variable. We gauge the extent of gender and racial home ownership gaps in Table 4 
through a simple decomposition analysis. ${ }^{15}$ Along the rows, householders in each gendered family type sample keep their characteristics, but their home ownership probabilities are calculated from each family type are calculated under a single family type coefficients. Along the diagonal are own predictions — what is the predicted probability of home ownership for householders in family type X using the coefficients of family type X. These help us to understand the impact of opportunities and barriers. The first panel shows these predictions for gendered family types without regard for race. The second panel documents the predictions for white and the third panel for African American householders. Any two predictions in the lower two panels can be used to explore differences in race and gender gaps in home ownership. ${ }^{16}$

Panel 1 confirms that gender differences principally reflect differences in family type. There is no significant increase home ownership if a female householder in a "non-married couple" family (predicted probability of ownership 48.3 percent) were to have the coefficients of a male householder in a "non-married couple" family (predicted probability of ownership 51.1 percent). Similarly, if a female householder in a non-family (predicted probability of ownership 57.7 percent) were to have the coefficients of a male householder in a non-family (predicted probability of ownership 57.6 percent) there would be little difference. But give a female householder in a "non-married couple" family the coefficients of either a male or female householder in a married couple and the probability of home ownership rises to 66.2 percent or 65.0 percent. Similarly, give a female householder in a non-family household the coefficients of either a male or female householder in a married couple and the probability of home ownership

\footnotetext{
${ }^{15}$ This is similar to a Oaxaca decomposition without the cross effects.

${ }^{16}$ Each household's characteristics remain the same even when the predictions come from the regression based on households with other characteristics. The income distribution of female heads of families remains the same whether we predict based on the male heads of couples or the male heads of non-families regressions. Also, these predictions are different from those in the graphs because the characteristics of the specific family type, but the overall sample characteristics of the entire sample are built into the graphs.
} 
rises to 78.3 percent or 82.2 percent. Similar increases are also observed for male householders in "non-married couple" families.

Comparing any two numbers in the same place in the two lower panels informs us about the predicted racial gap in home ownership within family type. For example, only 38 percent of African American female householders in "non-married couple" family households but 53 percent of white female householders in "non-married couple" family households are predicted to own homes using their own regimes - a significant racial gap of 15 percentage points within gender and family type. Of female householders in married couple households, African American women are 15 percentage points less likely to own their own homes than white women. So, for example, the race gap that is discussed by Collins and Margo (2001), is not just a result of differences in household structure and the higher rates of female headedness within the African American community. Within female headed households homeownership differs.

Comparing any two numbers on the diagonal within either panel informs us about gender and household organization gaps within race groups. Among African Americans, male householders in "non-married couple" families have a predicted home ownership probability of 44.4 percent, but it is only 37.9 percent for female householders. Among whites, male householders in "non-married couple" families have a predicted home ownership probability of 62.8 percent, but it is only 53.0 percent for female householders. But African American female householders of non-families (40.7 percent) are much more likely than African American male householders in non-families (30.6 percent) to own their own homes. The same is true for white householders in non-families (59.3 percent for women and 50.6 percent for men).

Comparing the numbers in any row in any table informs us about how home ownership for the same households would change if those households kept their own characteristics but 
used the coefficients from different family types. For example, African American female householders in "non-married couple" families find that their predicted ownership ranges from 55.4 percent to 24.5 percent depending on the family type coefficients of the home ownership prediction. The prediction for white female householders in "non-married couple" families varies from 71.0 percent to 45.9 percent. If both white female householders in "non-married couple" of families and African American female householders in "non-married couple" families had their home ownership determined by the regression based on male householders in married couple households, the predicted probability would be 71.0 percent for the white female householders, but only 55.4 percent for the African American female householders.

Every householder, whether man or women, white or African American, has the highest predicted probabilities of home ownership if he or she were to have the coefficients from a married couple household (with either a male or female householder). Without changing the characteristics of the householder (income remains the same, education remains the same, etc.) the predicted probability of home ownership increases substantially. Marriage appears to be powerful enough on its own to stimulate a demand for housing, to alter mortgage lenders decisions, or to change behaviors in ways that are more compatible with home ownership.

\section{Conclusion}

A number of patterns emerge from this analysis. The most striking is that the most important aspect of the homeownership gap across gender and family type exists for family type itself. Married couples are significantly more likely to own a home than either householders in "non-married couple" families or in non-families. While these differences are large across family types, they are not so pronounced with regard to gender. Within family type, female householders are about as likely to own a home as those male householders. One explanation 
associated with this result is that lower incomes in non-married couple households are transmitted into lower wealth — whether the householder is a man or a woman.

It is not clear why marriage so strongly influences housing outcomes. A lesson from this analysis is that gender differences may reflect marriage differences more than anything else. Being married is associated with a higher probability of home ownership, higher value and typically higher equity than not being married. We do not know whether behavior on the part of householders or behavior on the part of mortgage lenders (or both) that drives this difference.

The results from home Value and equity inform us that the gap in home ownership is mostly a question of getting one's foot in the door. Both value and equity ownership gaps exist, but they do not consistently favor one gender over another.

African Americans have substantially and significantly lower probabilities of home ownership and lower home values than whites. But they do not consistently have lower equity, suggesting that African Americans overinvest in housing relative to their economic means. While gaps in equity and total ownership exist across family types, these differences pale when compared with those for homeownership itself. Once householders s have entered into home ownership, they are much more similar to each other than before.

Wealth differentials represent long run disadvantages for individuals, an economic disparity that is transferred across generations. Therefore, programs that make homeownership more accessible can go a long way toward reducing differences in home wealth. Increasing accessibility to programs such as FHA mortgages and other efforts to reduce liquidity constraints could provide a significant reduction in existing wealth differentials. Programs that push a foot through the door offer the promise of a considerable decrease in wealth inequalities. 
Table 1

Distribution of Householders Across Family Types

by Gender and Race (Percent of Sample) ${ }^{17}$

\begin{tabular}{|c|c|c|c|}
\hline & $\begin{array}{l}\text { \% of Total } \\
\text { Sample }\end{array}$ & $\begin{array}{l}\text { \% of African } \\
\text { American } \\
\text { Householders in } \\
\text { Family Type }\end{array}$ & $\begin{array}{l}\text { \% of white } \\
\text { Householders in } \\
\text { Family Type }\end{array}$ \\
\hline \multicolumn{4}{|l|}{ Married Couple } \\
\hline Male Householder & 39.0 & 22.5 & 41.3 \\
\hline Female Householder & 16.1 & 12.2 & 16.6 \\
\hline \multicolumn{4}{|c|}{ Non-Married Couple, Family } \\
\hline Male Householder & 3.3 & 4.2 & 3.1 \\
\hline Female Householder & 11.3 & 28.0 & 8.9 \\
\hline \multicolumn{4}{|c|}{ Non-Married Couple, Non-family } \\
\hline Male Householder & 13.1 & 15.0 & 12.8 \\
\hline Female Householder & 17.3 & 18.1 & 17.2 \\
\hline Total & $100 \%$ & $100 \%$ & $100 \%$ \\
\hline
\end{tabular}

${ }^{17}$ Weights are used in this table. Percentages may not add to $100 \%$ due to rounding. 
Table 2

Means and Proportions for Variables used in the Analysis

by Family Type

(Standard deviation in parentheses for Means) $)^{18}$

\begin{tabular}{|c|c|c|c|c|c|c|}
\hline & Male--MC & Female--MC & Male--NCF & Female--NCF & Male--NF & Female--NF \\
\hline $\begin{array}{l}\text { High School } \\
\text { Education/Less }\end{array}$ & 0.43 & 0.40 & 0.57 & 0.55 & 0.46 & 0.52 \\
\hline Some College & 0.27 & 0.32 & 0.29 & 0.31 & 0.26 & 0.26 \\
\hline $\begin{array}{l}\text { Earned Income } \\
\text { (Monthly) } \\
\text { Retiree Earned } \\
\text { Income (Monthly) } \\
\text { Monthly Poverty } \\
\text { Income } \\
\text { Retiree }\end{array}$ & $\begin{array}{l}\$ 3666 \\
(\$ 3949) \\
\$ 653 \\
(\$ 204) \\
\$ 1220 \\
(\$ 348) \\
0.31\end{array}$ & $\begin{array}{l}\$ 4010 \\
(\$ 3816) \\
\$ 483 \\
(\$ 1881) \\
\$ 1242 \\
(\$ 351) \\
0.21\end{array}$ & $\begin{array}{l}\$ 2788 \\
(\$ 2803) \\
\$ 400 \\
(\$ 108) \\
\$ 1138 \\
(\$ 1065) \\
0.22\end{array}$ & $\begin{array}{l}\$ 1885 \\
(\$ 2001) \\
\$ 289 \\
(\$ 969) \\
\$ 1167 \\
(\$ 306) \\
0.19\end{array}$ & $\begin{array}{l}\$ 2207 \\
(\$ 2909) \\
\$ 241 \\
(\$ 930) \\
\$ 747 \\
(\$ 108) \\
0.33\end{array}$ & $\begin{array}{l}\$ 1176 \\
(\$ 1998) \\
\$ 164 \\
(\$ 672) \\
\$ 714 \\
(\$ 68) \\
0.56\end{array}$ \\
\hline Immigrant & 0.10 & 0.08 & 0.15 & 0.10 & 0.07 & 0.06 \\
\hline Latino/a & 0.08 & 0.07 & 0.11 & 0.09 & 0.05 & 0.03 \\
\hline African American & 0.07 & 0.09 & 0.16 & 0.31 & 0.14 & 0.13 \\
\hline Rural Residence & 0.47 & 0.47 & 0.49 & 0.47 & 0.51 & 0.48 \\
\hline $\begin{array}{l}\text { Large City } \\
\text { Residence }\end{array}$ & 0.24 & 0.25 & 0.25 & 0.25 & 0.21 & 0.24 \\
\hline Age & $\begin{array}{l}50 \\
(16)\end{array}$ & $\begin{array}{l}47 \\
(12)\end{array}$ & $\begin{array}{l}47 \\
(14)\end{array}$ & $\begin{array}{l}46 \\
(14)\end{array}$ & $\begin{array}{l}51 \\
(16)\end{array}$ & $\begin{array}{l}51 \\
(15)\end{array}$ \\
\hline $\begin{array}{l}\text { Widowed } \\
\text { Divorce/Separated } \\
\text { Home Ownership }\end{array}$ & 0.83 & 0.82 & $\begin{array}{l}0.24 \\
0.50 \\
0.61\end{array}$ & $\begin{array}{l}0.32 \\
0.52 \\
0.48\end{array}$ & $\begin{array}{l}0.24 \\
0.42 \\
0.49\end{array}$ & $\begin{array}{l}0.57 \\
0.21 \\
0.60\end{array}$ \\
\hline $\begin{array}{l}\text { Home Value (if } \\
\text { owned) }\end{array}$ & $\begin{array}{l}\$ 154,013 \\
(\$ 108,532)\end{array}$ & $\begin{array}{l}\$ 160,616 \\
(\$ 115,783)\end{array}$ & $\begin{array}{l}\$ 125,196 \\
(\$ 100.445)\end{array}$ & $\begin{array}{l}\$ 113,467 \\
(\$ 82,494)\end{array}$ & $\begin{array}{l}\$ 124,723 \\
(\$ 101,572)\end{array}$ & $\begin{array}{l}\$ 116,386 \\
(\$ 91,187)\end{array}$ \\
\hline $\begin{array}{l}\text { Home Equity (if } \\
\text { owned) }\end{array}$ & $\begin{array}{l}\$ 105,996 \\
\$(98,395)\end{array}$ & $\begin{array}{l}\$ 101,528 \\
(\$ 96,103)\end{array}$ & $\begin{array}{l}\$ 89,365 \\
(\$ 92,424)\end{array}$ & $\begin{array}{l}\$ 81,124 \\
(\$ 79,433)\end{array}$ & $\begin{array}{l}\$ 91,017 \\
(\$ 91,720)\end{array}$ & $\begin{array}{l}\$ 96,883 \\
(\$ 101,528)\end{array}$ \\
\hline $\begin{array}{l}\text { Ownership Time } \\
\text { (Years) }\end{array}$ & $\begin{array}{l}14 \\
(13)\end{array}$ & $\begin{array}{l}13 \\
(12)\end{array}$ & $\begin{array}{l}16 \\
(15)\end{array}$ & $\begin{array}{l}16 \\
(15)\end{array}$ & $\begin{array}{l}17 \\
(16)\end{array}$ & $\begin{array}{l}23 \\
(18)\end{array}$ \\
\hline FHA Mortgage & 0.15 & 0.16 & 0.16 & 0.17 & 0.13 & 0.08 \\
\hline $\begin{array}{l}\text { Weighted Sample } \\
\text { Size }\end{array}$ & $33,198,990$ & $13,698,867$ & $2,790,088$ & $9,620,332$ & $11,123,894$ & $14,775,531$ \\
\hline $\begin{array}{l}\text { Unweighted } \\
\text { Sample Size }\end{array}$ & 8,697 & 3,702 & 636 & 2,871 & 2,702 & 4.235 \\
\hline
\end{tabular}

\footnotetext{
${ }^{18}$ Male or Female is the gender of the householder. MC stands for married couple family, NCF stands for nonmarried couple family, NF stands for non-family. Weights are used in this table. Omitted characteristics found by subtracting from $100 \%$.
} 
Table 3

Regression Equation Coefficients Across Family Types

(Standard deviation in parentheses)

\begin{tabular}{|c|c|c|c|c|c|c|}
\hline & $\begin{array}{l}\text { Male-- } \\
\text { MC }\end{array}$ & $\begin{array}{l}\text { Female-- } \\
\text { MC }\end{array}$ & $\begin{array}{l}\text { Male-- } \\
\text { NCF }\end{array}$ & $\begin{array}{l}\text { Female-- } \\
\text { NCF }\end{array}$ & Male--NF & $\begin{array}{l}\text { Female-- } \\
\text { NF }\end{array}$ \\
\hline \multicolumn{7}{|c|}{ Home Ownership } \\
\hline $\begin{array}{l}\text { High School } \\
\text { Education/Less }\end{array}$ & $\begin{array}{l}-0.0205^{*} \\
(0.0106)\end{array}$ & $\begin{array}{l}-.0584^{*} \\
(0.0178)\end{array}$ & $\begin{array}{l}-0.0944 \\
(0.0648)\end{array}$ & $\begin{array}{l}-0.1536^{*} \\
(0.0338)\end{array}$ & $\begin{array}{l}-0.0238 \\
(0.0270)\end{array}$ & $\begin{array}{l}-0.1677^{*} \\
(0.0236)\end{array}$ \\
\hline Some College & $\begin{array}{l}-0.0076 \\
(0.0106)\end{array}$ & $\begin{array}{l}-0.0170 \\
(0.0175)\end{array}$ & $\begin{array}{l}-0.0697 \\
(0.0713)\end{array}$ & $\begin{array}{l}-0.0948^{*} \\
(0.0347)\end{array}$ & $\begin{array}{l}-0.0012 \\
(0.0253)\end{array}$ & $\begin{array}{l}-0.0661^{*} \\
(0.0255)\end{array}$ \\
\hline $\begin{array}{l}\text { Permanent Earned } \\
\text { Income (Monthly) }\end{array}$ & $\begin{array}{l}0.0005^{*} \\
(0.0000)\end{array}$ & $\begin{array}{l}0.0006^{*} \\
(0.0001)\end{array}$ & $\begin{array}{l}0.0009^{*} \\
(0.0001)\end{array}$ & $\begin{array}{l}0.0014^{*} \\
(0.0001)\end{array}$ & $\begin{array}{l}0.0007^{*} \\
(0.0001)\end{array}$ & $\begin{array}{l}0.0009 * \\
(0.0001)\end{array}$ \\
\hline $\begin{array}{l}\text { Permanent Earned } \\
\text { Income (Monthly) } \\
\text { Squared*10 }\end{array}$ & $\begin{array}{l}-0.0001^{*} \\
(0.0006)\end{array}$ & $\begin{array}{l}0.0004^{*} \\
(0.0000)\end{array}$ & $\begin{array}{l}0.0002^{*} \\
(0.0000)\end{array}$ & $\begin{array}{l}-0.0006^{*} \\
(0.0001)\end{array}$ & $\begin{array}{l}-0.0001 * \\
(0.0000)\end{array}$ & $\begin{array}{l}-0.0001 \\
(0.0003)\end{array}$ \\
\hline Latino/a & $\begin{array}{l}-0.0010 \\
(0.0152)\end{array}$ & $\begin{array}{l}-0.0745^{*} \\
(0.0294)\end{array}$ & $\begin{array}{l}-0.0853 \\
(0.0874)\end{array}$ & $\begin{array}{l}-0.0437 \\
(0.0404)\end{array}$ & $\begin{array}{l}-0.0824 \\
(0.0530)\end{array}$ & $\begin{array}{l}-0.1009 * \\
(0.0498)\end{array}$ \\
\hline African American & $\begin{array}{l}-0.0730^{*} \\
(0.0171)\end{array}$ & $\begin{array}{l}0.0759^{*} \\
(0.0237)\end{array}$ & $\begin{array}{l}-0.2159^{*} \\
(0.0581)\end{array}$ & $\begin{array}{l}-0.0597^{*} \\
(0.0239)\end{array}$ & $\begin{array}{l}-0.1696^{*} \\
(0.0293)\end{array}$ & $\begin{array}{l}-0.0742 * \\
(0.0226)\end{array}$ \\
\hline Rural Residence & $\begin{array}{l}-0.0500^{*} \\
(0.0088)\end{array}$ & $\begin{array}{l}-0.0285^{*} \\
(0.0141)\end{array}$ & $\begin{array}{l}-0.0145 \\
(0.0491)\end{array}$ & $\begin{array}{l}0.0541^{*} \\
(0.0244)\end{array}$ & $\begin{array}{l}0.0532^{*} \\
(0.0236)\end{array}$ & $\begin{array}{l}-0.0270 \\
(0.0187)\end{array}$ \\
\hline $\begin{array}{l}\text { Large City } \\
\text { Residence }\end{array}$ & $\begin{array}{l}-0.0251^{*} \\
(0.0117)\end{array}$ & $\begin{array}{l}-0.0348 \\
(0.0187)\end{array}$ & $\begin{array}{l}0.0490 \\
(0.0598)\end{array}$ & $\begin{array}{l}0.0668^{*} \\
(0.0288)\end{array}$ & $\begin{array}{l}0.0126 \\
(0.0236)\end{array}$ & $\begin{array}{l}0.0070 \\
(0.0226)\end{array}$ \\
\hline Age & $\begin{array}{l}0.0141^{*} \\
(0.0018)\end{array}$ & $\begin{array}{l}0.0088^{*} \\
(0.0035)\end{array}$ & $\begin{array}{l}0.0161 \\
(0.0100)\end{array}$ & $\begin{array}{l}0.0288^{*} \\
(0.0053)\end{array}$ & $\begin{array}{l}0.0296^{*} \\
(0.0049)\end{array}$ & $\begin{array}{l}0.0512 * \\
(0.0043)\end{array}$ \\
\hline Age Squared & $\begin{array}{l}-0.0001^{*} \\
(0.0000)\end{array}$ & $\begin{array}{l}0.0000 \\
(0.0000)\end{array}$ & $\begin{array}{l}-0.0001 \\
(0.0001)\end{array}$ & $\begin{array}{l}-0.002 * \\
(0.000)\end{array}$ & $\begin{array}{l}0.0002 * \\
(0.0000)\end{array}$ & $\begin{array}{l}-0.0004^{*} \\
(0.0000)\end{array}$ \\
\hline Widowed & & & $\begin{array}{l}0.02314 \\
(0.2052)\end{array}$ & $\begin{array}{l}0.1916^{*} \\
(0.0353)\end{array}$ & $\begin{array}{l}0.2152^{*} \\
(0.0357)\end{array}$ & $\begin{array}{l}0.1972 * \\
(0.0270)\end{array}$ \\
\hline Divorced/Separated & & & $\begin{array}{l}-0.0078 \\
(0.1337)\end{array}$ & $\begin{array}{l}0.0523 \\
(0.0273)\end{array}$ & $\begin{array}{l}0.0017 \\
(0.0235)\end{array}$ & $\begin{array}{l}-0.0173 \\
(0.0247)\end{array}$ \\
\hline \multicolumn{7}{|c|}{ Home Value (coefficients in \$) } \\
\hline $\begin{array}{l}\text { High School } \\
\text { Education/Less }\end{array}$ & $\begin{array}{l}-54,043 * \\
(2,807)\end{array}$ & $\begin{array}{l}-47,037 * \\
(4,772)\end{array}$ & $\begin{array}{l}-56,130 * \\
(13,776)\end{array}$ & $\begin{array}{l}-36,788^{*} \\
(6,490)\end{array}$ & $\begin{array}{l}-49,373 * \\
(6,491)\end{array}$ & $\begin{array}{l}-33,922 * \\
(4,662)\end{array}$ \\
\hline Some College & $\begin{array}{l}-37,344^{*} \\
(2,884)\end{array}$ & $\begin{array}{l}-36,199^{*} \\
(4,581)\end{array}$ & $\begin{array}{l}-32,435^{*} \\
(14,575)\end{array}$ & $\begin{array}{l}-22,492^{*} \\
(5,511)\end{array}$ & $\begin{array}{l}-33,027^{*} \\
(6,, 897)\end{array}$ & $\begin{array}{l}-19,705^{*} \\
(4,929)\end{array}$ \\
\hline $\begin{array}{l}\text { Permanent Earned } \\
\text { Income (Monthly) }\end{array}$ & $\begin{array}{l}58.64 * \\
(6.02)\end{array}$ & $\begin{array}{l}65.37 * \\
(11.05)\end{array}$ & $\begin{array}{l}121.11^{*} \\
(34.58)\end{array}$ & $\begin{array}{l}36.32 \\
(20.11)\end{array}$ & $\begin{array}{l}121.76^{*} \\
(16.07)\end{array}$ & $\begin{array}{l}63.27 * \\
(16.94)\end{array}$ \\
\hline $\begin{array}{l}\text { Permanent Earned } \\
\text { Income (Monthly) } \\
\text { Squared }\end{array}$ & $\begin{array}{l}0.67^{*} \\
(0.24)\end{array}$ & $\begin{array}{l}1.67^{*} \\
(0.50)\end{array}$ & $\begin{array}{l}-3.70 * \\
(1.67)\end{array}$ & $\begin{array}{l}4.51 * \\
(1.63)\end{array}$ & $\begin{array}{l}-0.94 \\
(0.63)\end{array}$ & $\begin{array}{l}1.84 \\
(1.04)\end{array}$ \\
\hline
\end{tabular}




\begin{tabular}{|lllllll|}
\hline Latino/a & $-12,380$ & $-11,296$ & 14,262 & $-17,404^{*}$ & $-3,056$ & $24,209^{*}$ \\
& $(5,118)$ & $(8,727)$ & $(21,122)$ & $(7,832)$ & $(14,606)$ & $(11,869)$ \\
African American & $-36,573^{*}$ & $-46,035^{*}$ & $-32,736^{*}$ & $-40,142^{*}$ & $-11,498$ & $-51,486^{*}$ \\
& $(4,543)$ & $(6,736)$ & $(13,967)$ & $(4,357)$ & $(8,945)$ & $(5,082)$ \\
Rural Residence & $-3,667$ & 688 & 10,718 & $2,183^{*}$ & 4,457 & $-6,427$ \\
& $(2,526)$ & $(4,166)$ & $(11,065)$ & $(4,328)$ & $(5,766)$ & $(3,872)$ \\
Large City & $50,840^{*}$ & $50,233^{*}$ & $28,038^{*}$ & $38,588^{*}$ & $29,957^{*}$ & $42,989^{*}$ \\
Residence & $(3,006)$ & $(4,957)$ & $(13,101)$ & $(4,903)$ & $(6,834)$ & $(4,565)$ \\
& \multicolumn{7}{c}{} & & & \\
& Home Equity & $($ Coefficients in \$) & & \\
High School & $-21,822^{*}$ & $-34,991^{*}$ & $-25,528$ & $-22,929^{*}$ & $-4,364$ & $-14,371$ \\
Education/Less & $(3,183)$ & $(5,348)$ & $(16,060)$ & $(6,945)$ & $(11,652)$ & $(8,909)$ \\
Some College & $-15,431^{*}$ & $-22,973^{*}$ & $-15,299$ & $-14,494^{*}$ & $-5,516$ & $-5,247$ \\
& $(3,034)$ & $(4,921)$ & $(14,907)$ & $(6,182)$ & $(9,379)$ & $(6,418)$ \\
Permanent Earned & $-15.35^{*}$ & -14.50 & -5.71 & -38.28 & -28.12 & $-38.49 *$ \\
Income (Monthly) & $(5.61)$ & $(10.61)$ & $(34.24)$ & $(20.09)$ & $(25.14)$ & $(17.06)$ \\
Permanent Earned & $1.31 *$ & $3.83^{*}$ & 0.64 & $8.10^{*}$ & $1.43 *$ & 1.77 \\
Income (Monthly) & $(0.04)$ & $(0.49)$ & $(1.59)$ & $(1.74)$ & $(0.64)$ & $(1.10)$ \\
Squared & $-7,195$ & $-12,482$ & 11,968 & $-8,760$ & $-4,590$ & $-10,454$ \\
Latino/a & $(5,040)$ & $(8,692)$ & $(20,165)$ & $(8,405)$ & $(14,542)$ & $(13,045)$ \\
& $-21,309^{*}$ & $-38,399^{*}$ & $-17,083$ & $-36,051^{*}$ & 2,236 & $-30,182^{*}$ \\
African American & $(4,657)$ & $(7,166)$ & $(14,727)$ & $(6,205)$ & $(9,177)$ & $(1,129)$ \\
& -237 & 1,247 & 3,151 & 4,372 & 2,724 & $-4,594$ \\
Rural Residence & $(2,473)$ & $(4,108)$ & $(10,785)$ & $(4,462)$ & $(5,612)$ & $(4,030)$ \\
Large City & $28,953^{*}$ & $43,189^{*}$ & 20,625 & $37,263^{*}$ & 16,089 & $29,718^{*}$ \\
Residence & $(3,208)$ & $(5,274)$ & $(13,264)$ & $(6,095)$ & $(8,768)$ & $(9,686)$ \\
Wald Statistic & 1451.88 & 666.76 & 50.13 & 277.03 & 184.58 & 339.49 \\
Probability & 0.00 & 0.00 & 0.00 & 0.00 & 0.00 & 0.00 \\
\hline
\end{tabular}

Male or Female is the gender of the householder. MC stands for married couple family, NCF stands for non-married couple family, NF stands for non-family. Starred Coefficients are significant at the 5\% level. The marginal values, rather than the actual coefficients, are reported for the home ownership equation. All three equations also retiree earnings and retiree earnings squared, monthly poverty earnings, , whether an immigrant, and a constant term. Home ownership also includes number of kids in the household. Value and Equity also include length of home ownership and whether the home was financed through an FHA mortgage. Whether widowed or divorced was never significant for the value or equity equations and are not reported here. 
Figure 1

Predicted Probability of Home Ownership

Using Coefficients From Specific Family Type Regressions and All Householders' Characteristics ${ }^{19}$

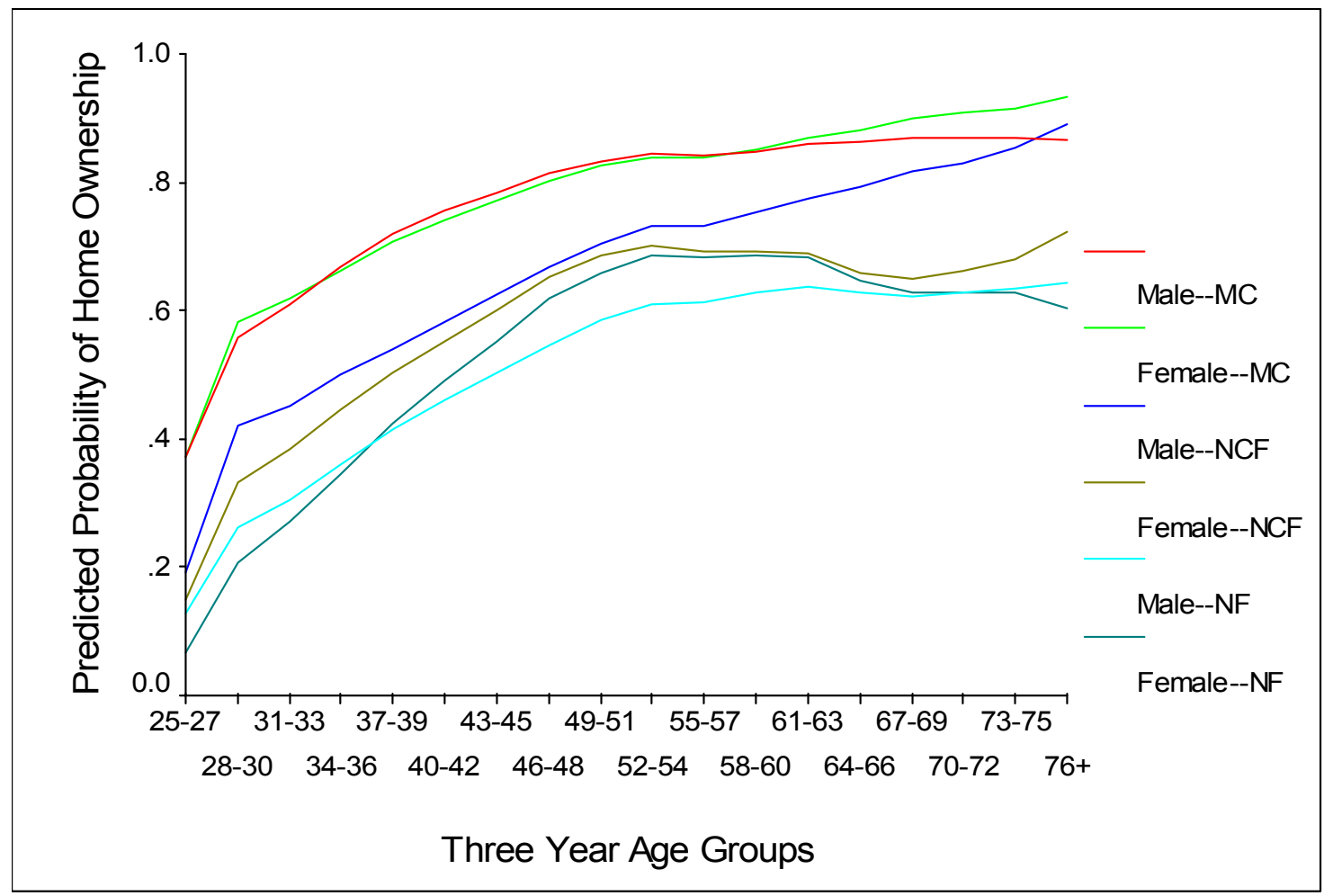

\footnotetext{
${ }^{19}$ The probability of home ownership is predicted from the estimation results in Table 3 , Panel 1 . The coefficients of each equation are applied to the individual characteristics of every single person in the sample, regardless of the family type in which the person is a householder. Each line uses the coefficients from a different family type as labeled in the legend. Male or Female is the gender of the householder. MC stands for married couple family, NCF stands for non-married couple family, NF stands for non-family. This graph uses weights.
} 
Figure 2

Predicted Home Value

Using Coefficients From Specific Family Type Regressions and All Householders' Characteristics $^{20}$

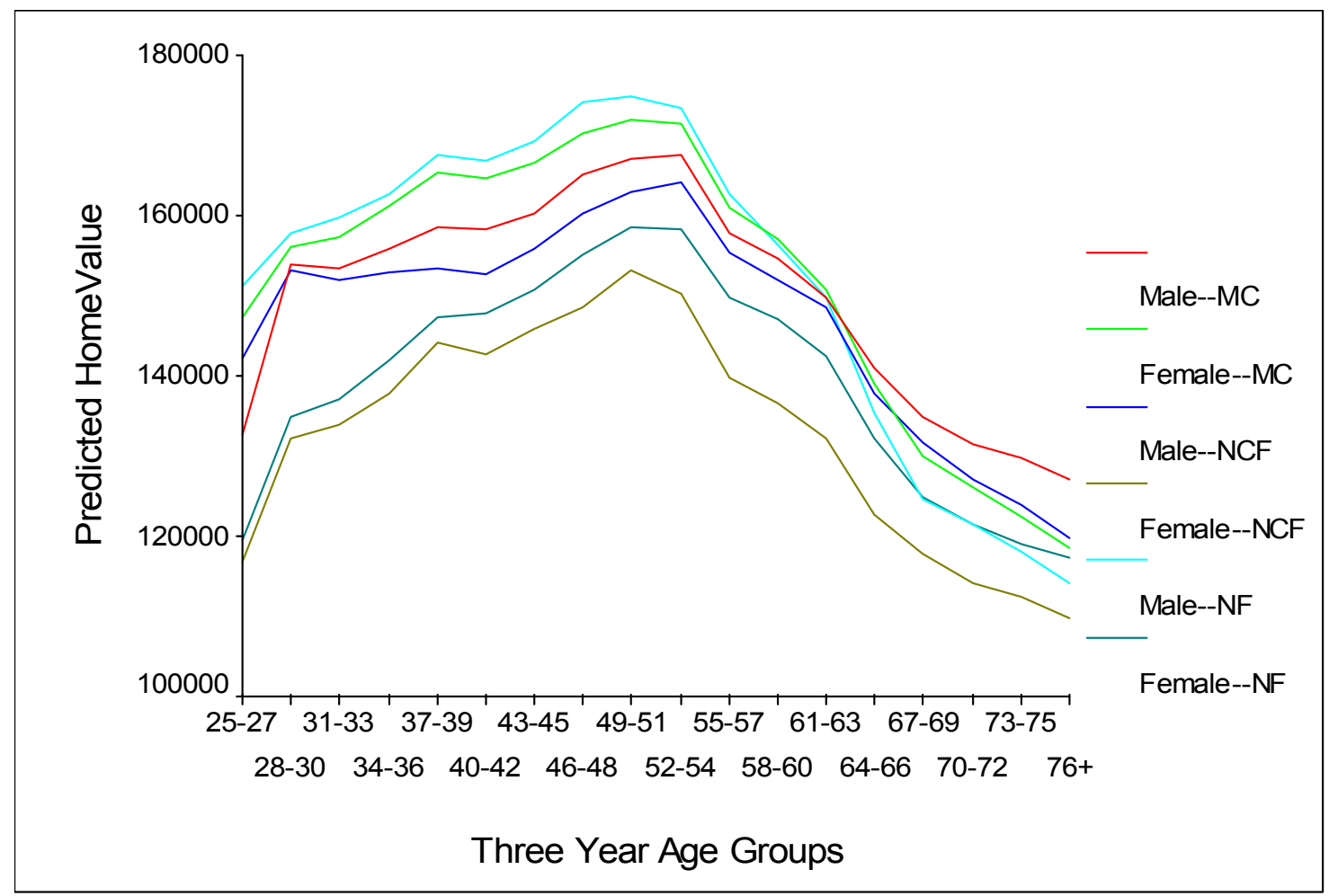

\footnotetext{
${ }^{20}$ Value is predicted from the estimation results in Table 3, Panel 2. The coefficients of each prediction are applied to the individual characteristics of every single person in the sample, regardless of the family type in which the person is a householder. Each line uses the coefficients from a different family type as labeled in the legend. Male or Female is the gender of the householder. MC stands for married couple family, NCF stands for non-married couple family, NF stands for non-family. This graph uses weights.
} 
Figure 3

Predicted Home Equity

Using Coefficients From Specific Family Type Regressions and All Householders' Characteristics $^{21}$

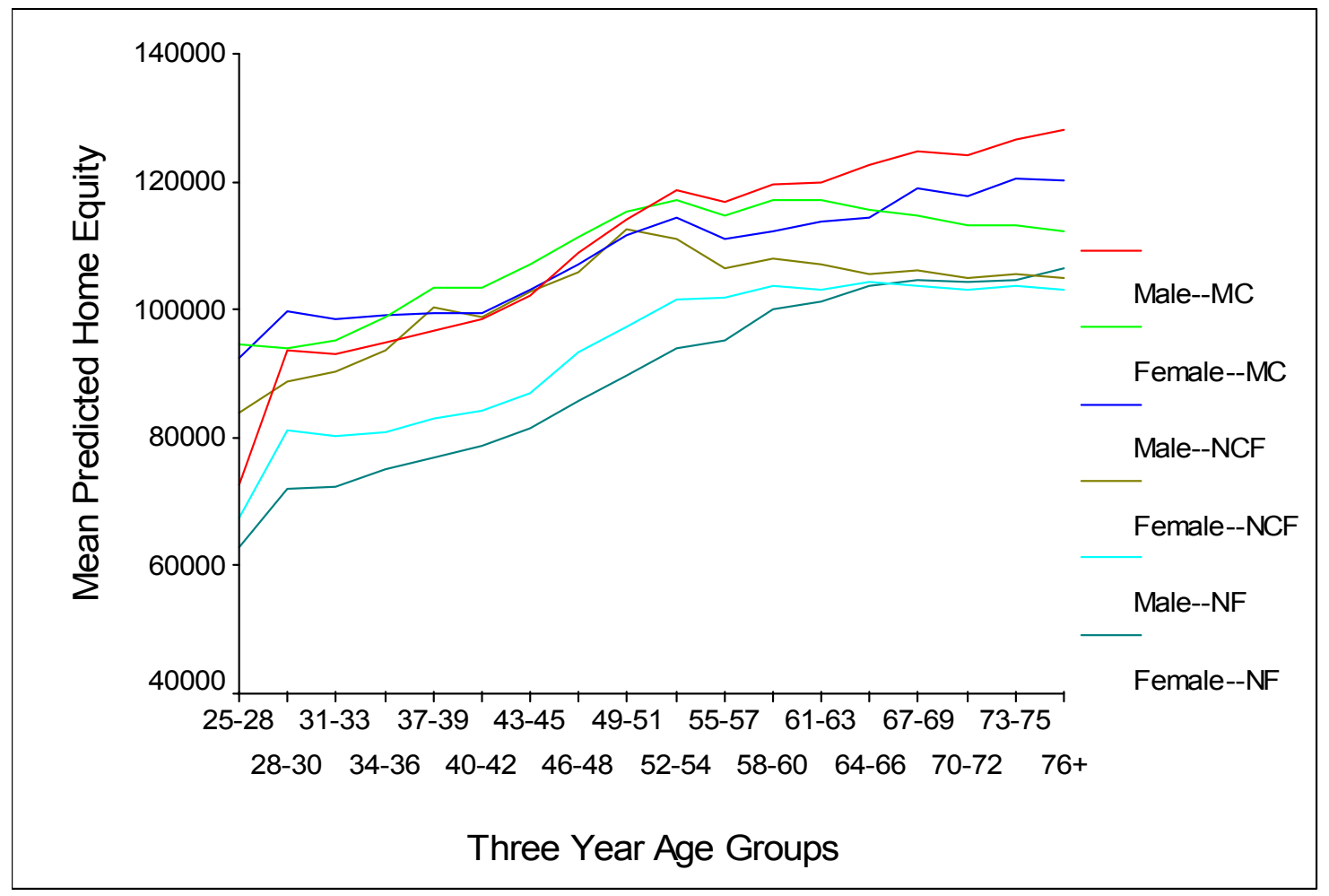

\footnotetext{
${ }^{21}$ Equity is predicted from the estimation results in Table 3, Panel 3. The coefficients of each prediction are applied to the individual characteristics of every single person in the sample, regardless of the family type in which the person is a householder. Each line uses the coefficients from a different family type as labeled in the legend. Male or Female is the gender of the householder. MC stands for married couple family, NCF stands for non-married couple family, NF stands for non-family. This graph uses weights.
} 
Table 4

Predicted Probability of Homeownership

by Family Type, Gender, and Race of the Householder

Decomposition Matrix

(standard deviations of predictions in parentheses)

\begin{tabular}{|c|c|c|c|c|c|c|}
\hline \multicolumn{7}{|c|}{$\begin{array}{l}\text { Columns: Coefficients Based on Family Type } \\
\text { Rows: Characteristics Based on Family Type }\end{array}$} \\
\hline & Male--MC & Female--MC & Male--NCF & Female--NCF & Male--NF & Female--NF \\
\hline \multicolumn{7}{|c|}{ Householders of Both Races } \\
\hline Male--MC & $\begin{array}{l}.832 \\
(.141)\end{array}$ & $\begin{array}{l}.834 \\
(.157)\end{array}$ & $\begin{array}{l}.705 \\
(.199)\end{array}$ & $\begin{array}{l}.630 \\
(.210)\end{array}$ & $\begin{array}{l}.550 \\
(.177)\end{array}$ & $\begin{array}{l}.586 \\
(.223)\end{array}$ \\
\hline Female--MC & $\begin{array}{l}.813 \\
(.147)\end{array}$ & $\begin{array}{l}.810 \\
(.157)\end{array}$ & $\begin{array}{l}.670 \\
(.204)\end{array}$ & $\begin{array}{l}.603 \\
(.213)\end{array}$ & $\begin{array}{l}.522 \\
(.178)\end{array}$ & $\begin{array}{l}.558 \\
(.222)\end{array}$ \\
\hline Male--NCF & $\begin{array}{l}.732 \\
(.179)\end{array}$ & $\begin{array}{l}.730 \\
(.186)\end{array}$ & $\begin{array}{l}.599 \\
(.227)\end{array}$ & $\begin{array}{l}.560 \\
(.234)\end{array}$ & $\begin{array}{l}.476 \\
(.209)\end{array}$ & $\begin{array}{l}.474 \\
(235)\end{array}$ \\
\hline Female--NCF & $\begin{array}{l}.662 \\
(.202)\end{array}$ & $\begin{array}{l}.650 \\
(.219)\end{array}$ & $\begin{array}{l}.511 \\
(.259)\end{array}$ & $\begin{array}{l}.483 \\
(.259)\end{array}$ & $\begin{array}{l}.413 \\
(.223)\end{array}$ & $\begin{array}{l}.420 \\
(.249)\end{array}$ \\
\hline Male--NF & $\begin{array}{l}.731 \\
(.172)\end{array}$ & $\begin{array}{l}.757 \\
(.182)\end{array}$ & $\begin{array}{l}.643 \\
(.219)\end{array}$ & $\begin{array}{l}.559 \\
(.220)\end{array}$ & $\begin{array}{l}.477 \\
(.190)\end{array}$ & $\begin{array}{l}.479 \\
(.216)\end{array}$ \\
\hline Female--NF & $\begin{array}{l}.783 \\
(.141)\end{array}$ & $\begin{array}{l}.822 \\
(.156)\end{array}$ & $\begin{array}{l}.746 \\
(.196)\end{array}$ & $\begin{array}{l}.649 \\
(.184)\end{array}$ & $\begin{array}{l}.576 \\
(.179)\end{array}$ & $\begin{array}{l}.577 \\
(.183)\end{array}$ \\
\hline \multicolumn{7}{|c|}{ White Householders } \\
\hline Male--MC & $\begin{array}{l}.840 \\
(.135)\end{array}$ & $\begin{array}{l}.842 \\
(.147)\end{array}$ & $\begin{array}{l}.722 \\
(.189)\end{array}$ & $\begin{array}{l}.636 \\
(.208)\end{array}$ & $\begin{array}{l}.562 \\
(.172)\end{array}$ & $\begin{array}{l}.593 \\
(.221)\end{array}$ \\
\hline Female--MC & $\begin{array}{l}.823 \\
(.136)\end{array}$ & $\begin{array}{l}.824 \\
(.148)\end{array}$ & $\begin{array}{l}.694 \\
(.188)\end{array}$ & $\begin{array}{l}.615 \\
(.211)\end{array}$ & $\begin{array}{l}.541 \\
(.170)\end{array}$ & $\begin{array}{l}.570 \\
(.220)\end{array}$ \\
\hline Male--NCF & $\begin{array}{l}.747 \\
(.177)\end{array}$ & $\begin{array}{l}.746 \\
(.184)\end{array}$ & $\begin{array}{l}.628 \\
(.218)\end{array}$ & $\begin{array}{l}.569 \\
(.237)\end{array}$ & $\begin{array}{l}.499 \\
(.207)\end{array}$ & $\begin{array}{l}.483 \\
(241)\end{array}$ \\
\hline Female--NCF & $\begin{array}{l}.710 \\
(.182)\end{array}$ & $\begin{array}{l}.702 \\
(.199)\end{array}$ & $\begin{array}{l}.588 \\
(.234)\end{array}$ & $\begin{array}{l}.530 \\
(.253)\end{array}$ & $\begin{array}{l}.470 \\
(.214)\end{array}$ & $\begin{array}{l}.459 \\
(.248)\end{array}$ \\
\hline Male--NF & $\begin{array}{l}.753 \\
(.159)\end{array}$ & $\begin{array}{l}.780 \\
(.168)\end{array}$ & $\begin{array}{l}.680 \\
(.198)\end{array}$ & $\begin{array}{l}.579 \\
(.216)\end{array}$ & $\begin{array}{l}.506 \\
(.180)\end{array}$ & $\begin{array}{l}.499 \\
(.214)\end{array}$ \\
\hline Female--NF & $\begin{array}{l}.802 \\
(.127)\end{array}$ & $\begin{array}{l}.842 \\
(.139\end{array}$ & $\begin{array}{l}.779 \\
(.170)\end{array}$ & $\begin{array}{l}.666 \\
(.175)\end{array}$ & $\begin{array}{l}.602 \\
(.166)\end{array}$ & $\begin{array}{l}.593 \\
(.176)\end{array}$ \\
\hline \multicolumn{7}{|c|}{ African American Householders } \\
\hline Male--MC & $\begin{array}{l}.733 \\
(.173)\end{array}$ & $\begin{array}{l}.727 \\
(.179)\end{array}$ & $\begin{array}{l}.497 \\
(.206)\end{array}$ & $\begin{array}{l}.542 \\
(.213)\end{array}$ & $\begin{array}{l}.395 \\
(.166)\end{array}$ & $\begin{array}{l}.493 \\
(.222)\end{array}$ \\
\hline
\end{tabular}




\begin{tabular}{|lllllll|}
\hline Female--MC & .689 & $\mathbf{. 6 7 7}$ & .435 & .490 & .340 & .438 \\
& $(.159)$ & $\mathbf{( . 1 7 5 )}$ & $(.195)$ & $(.199)$ & $(.146)$ & $(.200)$ \\
Male--NCF & .652 & .650 & $\mathbf{4 4 4}$ & .515 & .355 & .425 \\
& $(.172)$ & $(.176)$ & $\mathbf{( . 2 0 8 )}$ & $(.215)$ & $(.174)$ & $(.193)$ \\
Female--NCF & .554 & .534 & .337 & $\mathbf{. 3 7 9}$ & .245 & .334 \\
& $(.204)$ & $(.217)$ & $(.225)$ & $\mathbf{( . 2 4 6 )}$ & $(.186)$ & $(.230)$ \\
Male--NF & .594 & .618 & .420 & .441 & $\mathbf{. 3 0 6}$ & .358 \\
& $(.183)$ & $(.200)$ & $(.206)$ & $(.209)$ & $\mathbf{( . 1 5 3 )}$ & $(.189)$ \\
Female--NF & .658 & .687 & .526 & .532 & .398 & $\mathbf{. 4 0 7}$ \\
& $(.167)$ & $(.192)$ & $(.213)$ & $(.200)$ & $(.168)$ & $\mathbf{( . 1 8 6 )}$ \\
\hline
\end{tabular}

The probability of home ownership is predicted from the estimation results in Table 3, Panel 1. The coefficients of each prediction are applied to the individual characteristics of the sample actually used in that regression. Each row or column uses both the coefficients and the characteristics from a different family type as labeled. Male or Female is the gender of the householder. MC stands for married couple family, NCF stands for non-married couple family, NF stands for non-family. This table uses weights. 


\section{Reference List}

Blau, Francine and John W. Graham. 1990. "Black-White Differences in Asset Accumulation." Quarterly Journal of Economics. 105 (2), 321-339.

Bostic, Rafael W. and Brian J. Surette. 2000. Have the Doors Opened Wider: Trends in Home Ownership Rates by Race and Income.

Bostic, Rafael W. Paul S. Calem and Susan M. Wachter. 2004. " Hitting the Wall: Credit Constraints to Home Ownership." Joint Center for Housing Studies Working Paper, Harvard University. BABC 04-5

Caner, Asena and Edward Wolff. 2003. Asset Poverty in the United States 1984-1999:Evidence from the Panel Study of Income Dynamics. Levy Institute of Economics Working Paper No. 356.

Collins, William J. and Robert A. Margo. 2001. Race and Home Ownership in Twentieth Century America: The Role of Sample Composition. Vanderbilt University Working Paper, 01-W10.

Gyourko, Joseph and Peter Linneman. 1996. "Analysis of the changing Influences on Traditional Households’ Ownership Patterns." Journal of Urban Economics. 39 318-341.

Iannides, Yannis M. and Stuart S. Rosenthal. 1994. "Estimating the Consumption and Investment Demands for Housing and their Effect on Housing Tenure Status." Review of Economics and Statistics. 76 (1), 126-141. 
Macdonald, Martha. 1995. "Feminist Economics: From Theory to Research." The Canadian Journal of Economics. 28 (1), 159-176.

Munnell, Alicia Geoffrey Totell Lynn Browne and James McEneaney. 1996. "Mortgage Lending in Boston: Interpreting HMDA data." American Economic Review. 86 (1), 25-53.

Quercia, Roberto G. George W. McCarthy and Susan M. Wachter. "The Impacts of Affordable Lending Efforts on Homeownership Rates." Journal of Housing Economics, 2003, 12 2959

Robinson, Judith K. 2002. " Race, Gender, and Familial Status: Discrimination in One US Mortgage Market." Feminist Economics. 8 (2), 63-85.

Seidman, Ellen and Jennifer Tescher. 2004. From Unbanked to Homeowner: Improving the Supply of Financial Services to Low-Income Low-Asset Consumers. Harvard University Joint Center for Housing Studies Working Paper Series, BABC 04. 4.

Smith, Susan. 1990. Income, Housing Wealth, and Gender Inequality. Urban Studies. 27(1):6788.

United States Bureau of the Census. Children's Living Arrangements and Characteristics (Table A1). 2003a.

United States Bureau of the Census. Homeownership Rates by Age of Householder and Family Status for the United States (Table 15). 2003b .

Warren, Tracy, Karen Rowlingson and Clair Whyley. 2000. Gender and Wealth Inequality. Radical Statistics. 75: 49-54. 